\title{
Workforce Ageing and Labour Productivity in Europe
}

\author{
Iñigo Calvo-Sotomayor ${ }^{1, *}$, Jon Paul Laka ${ }^{2}$ and Ricardo Aguado ${ }^{3}$ \\ 1 Department of Strategy and Information Systems, University of Deusto, 48007 Bilbao, Spain \\ 2 Department of Quantitative Methods, University of Deusto, 48007 Bilbao, Spain; jplaka@deusto.es \\ 3 Department of Economics, University of Deusto, 48007 Bilbao, Spain; ricardo.aguado@deusto.es \\ * Correspondence: inigo.calvo@deusto.es
}

Received: 27 September 2019; Accepted: 18 October 2019; Published: 22 October 2019

\begin{abstract}
This article analyses the influence of workforce ageing on labour productivity in Europe. This question is relevant because of the impact it may have on economic activity, social security systems sustainability and the wellbeing of the population. The method applied is a quantitative contrast using the panel data technique for 24 countries in the period 1983-2014. This research is framed in the open conversation in the literature on the possible impact of ageing on productivity and takes as reference the seminal work of James Feyrer and the contrast model developed by Shekhar Aiyar, Christian Ebeke, and Xiaobo Shao. The results obtained show how a $1 \%$ increase in the workforce between the ages of 55 and 64 is related to a decrease of the annual increase in productivity between $-0.106 \%$ and $-0.479 \%$. The main contribution of the article is to provide, as far as the authors are aware, the first evidence of this negative relationship for the period 1983-2014, in addition to suggesting that the influence of ageing on productivity may be reduced by the evolution of the economies in question toward capital and/or knowledge-intensive sectors.
\end{abstract}

Keywords: ageing; productivity; workforce ageing; Europe

\section{Introduction}

This article analyses the effect of labour force ageing on labour productivity. This is a relevant area of research, given that population ageing has been catalogued as one of the major demographic trends of the present century and is a phenomenon that will influence practically all countries in the coming decades [1,2]. For this reason, the description, analysis, and understanding of the effects of ageing are of vital importance in order to turn it into a "pleasant macroeconomic experience" [3] and to ensure the sustainability not only of the provision of care and health services [4] but also of the welfare state as a whole [5]. Population ageing is relevant to sustainability issues because demographic change has broad economic and social consequences for the well-being of present and future generations. Europe was the first geographical area to experience the phenomenon and today is the oldest at the international level [6], so it is an appropriate region to contrast the possible effects of ageing.

This research is framed within the open debate in the scientific literature on the possible impact of labour force ageing on productivity, a debate in which conclusive results have not yet been reached. Since the seminal article by Feyrer [7], the research carried out is divided between those authors who defend a significant and negative relationship between these variables [7-10] and those who do not observe such a relationship [11-15]. The differences may lie in the analysis level used [8], given that investigations that have found a significant and negative relationship have used an aggregate productivity level (country level), while those that have not found this relationship focus on the micro level of economic industry or enterprise.

The challenge relies on the fact that the effects of ageing on a worker's skills are multiple and varied $[16,17]$. It seems that, in the scientific literature, there are different opinions regarding which 
sectors and occupations may be most affected by population ageing. For example, Veen [18] argues that age has a neutral effect on people employed in the banking sector, while a recent study [15] argues, after analysing a staff sample from a major Spanish bank, that older and more educated employees may be more productive than younger and less educated colleagues. Another added difficulty is the conceptualization of the term "productivity", given that it is a variable whose dynamics and causal mechanisms are difficult to grasp and understand $[14,19,20]$.

The research problem analysed in this article is whether there is a significant relationship between labour force ageing and labour productivity in a sample of 24 European countries between 1983 and 2014. For this purpose, the panel data analysis is used to estimate the model. The starting hypothesis is that there is a significant relationship between the two variables and that a greater labour force ageing (independent variable) negatively influences labour productivity (dependent variable). The research carried out follows the line proposed by Feyrer [7] and the model subsequently extended by Aiyar et al. [8]. The results discussed below support the hypothesis that labour force ageing is negatively related to labour productivity, although it is also shown that the effect is smaller than that proposed by Aiyar et al. for the same sample of countries between 1950 and 2014.

The objective of the present research is to continue deepening the path opened by these authors and to contribute with ideas and data to a little researched field in the population ageing studies [21]. As far as the authors know, this is the first time that the possible relationship between ageing and productivity is analysed in Europe between 1983 and 2014, a period of special interest due to the pronounced ageing process experienced by European society [22] and the second wave of productivity increase identified in the USA and European countries between 1995 and 2004 [23].

The results and debate raised by this article are important to continue advancing on the knowledge of the effects of demographic ageing and try to glimpse what consequences of the phenomenon are real socio-economic challenges [14]. This research is therefore part of the effort in the scientific literature to continue understanding the effect of ageing on economic activity, employment, and public services sustainability [24-26]. The analysis is particularly relevant for European countries, since the high average age shown by their societies poses major challenges in terms of changes in their productive structure, provision of care to their population, and updating their social security systems. In this sense, the sustainability of Europe's economic productivity, as well as its welfare state, may come from its capacity to manage the growing phenomenon of population ageing.

The article is organized as follows: in Section 2 the reference literature is presented, the Section 3 exposes the empirical design proposed, as well as the available data and a brief descriptive analysis, then results are presented and its debate is carried out based on the empirical contrast. Finally, the conclusions, limitations, and future lines of research are exposed.

\section{Research and Reference Literature}

The labour factor is one of the basic inputs for any economy, as the different age cohorts of a society have different needs and productive capacities, so changes in the demographic pyramid of a country will have social and economic effects [27]. In any case, the influence of the ageing phenomenon on productivity has not been analysed in a broad way, and, specifically, the literature investigating a possible relationship between demographic structure and aggregate productivity at country level is surprisingly small [21].

\subsection{An Ongoing Debate}

There are authors who have pointed out that population ageing may influence the productivity variable in one way or another [28-36], but they do not usually analyse a possible relationship in depth or contrast it with data. Among the scientific research that has addressed in detail and/or empirically checked a possible connection between population ageing and labour productivity at different levels of analysis (country, sectoral, regional, business, or individual level), there are two opposing positions. 
On the one hand, there exist authors who do defend a significant and negative relationship [7-10] and, on the other, those who do not believe that ageing has a decisive and negative influence on labour productivity [11-15,37]. In this regard, it is important to point out that those who defend a negative relationship have carried out their contrasts and analysis at the macro or aggregate level-that is, taking countries as unit of analysis-while authors who have not found such a relationship have taken their contrasts to a lower level of analysis. So, it seems that the differences could lie in the level of analysis used [8]. This in turn reinforces the idea that studies on population ageing face the challenge of overcoming "level myopia" [38], or how to analyse the micro aspects of this phenomenon without neglecting the context or macro aspects.

One of the first structured efforts to promote a scientific debate on the possible relationship between demographic ageing and productivity was made in 2004 at the symposium on Population Ageing and Economic Productivity organized by the Vienna Institute of Demography of the Austrian Academy of Sciences. At the meeting participants discussed a possible relationship between demographic ageing and productivity, but it was only an approximation given that a consensual position was not reached, and the organizers themselves encouraged further research.

In this symposium Prskawetz [39] stressed that demographic ageing is going to affect the current size and composition of the labour force, and that industrialized countries are going to have to achieve the same output with a shrinking and ageing labour force. Hence the importance of how population ageing can affect productivity. Prskawetz [39] also notes that during the debate at the symposium two visions emerged. On the one hand, the vision defended by Lindh [20]—qualified as "neutral" — that exposes the difficulty of giving answer to the question since the productivity measures themselves are controversial within the economic field. For this reason, it must be carefully chosen and explained at what level productivity is measured, given that it can be at the individual, productive plant, economic sector, national or global economy level. In addition, Lindh himself defends that productivity is actually "a system attribute" [20] rather than a variable linked to the individual and warns that it is not very useful to reach a priori conclusions on this issue. So, he rejects the assumption of a possible negative relationship between demographic ageing and productivity.

On the other hand, Skirbekk [40] argues that population ageing negatively affects productivity. His argument is based on the fact that, in general, the physical and mental abilities of the worker such as physical strength, sensory abilities, health or learning capacity and speed decline with age. Additionally, he notes that in certain professions-particularly those where experience and communication skills are important-older workers may perform as well as the average workforce, but he rules out the possibility that the European labour market may have sufficient flexibility to accommodate this change of the workforce age structure. He also admits that medical advances and increased levels of education can mitigate this negative impact, but he does not believe that they can neutralize or reverse them.

In summary, during the Population Ageing and Economic Productivity symposium, there were two lines of argument and debate advocated by Lindh and Skirbekk, which were also debated by other participants [41]. On one side are those who argue that demographic ageing in general, and labour force ageing in particular, does not and will not have a significant impact on productivity, while other authors argue for the negative influence of population ageing on productivity.

Independently of not reaching a consensus position, two relevant ideas emerge when addressing a possible relationship between these variables:

- The importance of defining the level of analysis, that is, whether productivity will be measured at the individual, plant, company, sector, region, or country level.

- The need to conceptualize well what is meant by "productivity".

The first reflection highlights the challenge of trying to avoid the aforementioned "level myopia" [38]. This means not to focus solely on the micro aspects of ageing, and adopting approaches that broaden the gaze towards social and contextual aspects in order to achieve greater explanatory capacity. Along these lines, an excessive focus on the individual productivity of working people -and 
their progressive decline as they age- as a hypothesis to explain a possible negative relationship between ageing and productivity may fall into this myopia, as it does not contemplate explanatory aspects that may reside at levels above the individual [42]. The note regarding the need to clearly define the productivity variable stresses the importance of an optimum specification of concepts for carrying out research $[43,44]$.

Taking into account the need to define the level of analysis and correctly conceptualise the explained variable, two of the most significant scientific articles that have addressed a possible relationship between labour force ageing and labour productivity at country level are analysed below, as this research addresses the possible relationship between these two variables for 24 European countries. It should be remembered that one of the objectives of this article is to continue along the path opened up by the research described in the following section.

\subsection{Ageing Workforce and Productivity at the Country Level: Two Researches in Search of an Answer}

The main research references for this paper are those conducted by James Feyrer [7,9] and Shekhar Aiyar, Christian Ebeke, and Xiaobo Shao of the European Department of the International Monetary Fund [8].

\subsubsection{Demographics and Productivity [7]}

James Feyrer [7] carried out one of the first known analyses in relation to the search of a possible relationship between demographic ageing and productivity variables, so it could be considered as the seminal article in this field of knowledge. In this research, Feyrer argued that the literature on productivity had neglected the possible influence of demographic ageing on aggregate productivity and, specifically, the possible impact of the labour force age structure on productivity.

The author conducted a longitudinal study between 1960 and 1995 taking into account the age cohort structure of the labour force of the economies under study and their aggregate productivity. Data on age and demographic cohorts were obtained from both the International Labour Organization (ILO) and the United Nations (UN), while data on productivity came from the Penn World Table (version 6.0). Two different samples were considered-the first was made up of 87 countries (all countries for which data were available, excluding oil exporters), and the second was made up of 19 OECD member countries.

Feyrer found a strong and significant relationship between the age structure of the labor force and aggregate productivity at the country level. Specifically, he argued that an increase in the age cohort of the workers between 40 and 50 years old led to improvements in productivity, while cohorts between 15 and 39 were associated with lower productivity. For cohorts aged 50-59 and over 60, the relationship was also negative, but the data were less robust and conclusive. He also discarded throughout the article the reverse causality or that it was aggregate productivity that was influencing productivity [7]. The author ended the article by pointing out that he did not attempt to explain the causal mechanism that existed between the variables studied, and concluded by defending that more research was necessary to continue advancing in this field of knowledge.

Finally, it is interesting to note that Feyrer [9] soon after published another article entitled "Aggregate Evidence on the Link Between Age Structure and Productivity", in which he pointed out two hypotheses to explain the causal mechanism that provoked the exposed relationship in the first article. One hypothesis stated that innovative activity was age-related, while the second hypothesis revolved around the age of people in managerial positions in the United States. He also closed this article by stating again that more research was still needed to address this issue in order to arrive at conclusive ideas.

\subsubsection{The Impact of Workforce Aging on European Productivity [8]}

In 2016, three members of the European Department of the International Monetary Fund (IMF) published a working paper analysing the effect of labour force ageing on labour productivity in the 
European Union, as well as suggesting possible policies that could be implemented. Aiyar, Ebeke, and Shao [8] carried out this research since Europe is experiencing a marked ageing process, and it is relevant to advance in the study of the possible impact that changes in the demographic structure may have on labour productivity. To do so, they took as a basis the work of Feyrer [7] and conducted a longitudinal analysis of 23 of the 28 countries that currently make up the EU, plus Norway, between 1950 and 2014. Data on the structure of the labour force were obtained from the OECD, and data on productivity were obtained from the Penn World Tables (version 9.0).

Its statistically significant findings suggested that labour force ageing had a negative impact on labour productivity, measured as an increase in real output per person employed. Specifically, they argued that a $1 \%$ increase in the age cohort of 55-64 years old was associated with a $0.165-0.7 \%$ reduction in annual productivity growth.

According to the authors, Spain, Italy, Portugal, Greece, and Ireland were the European countries that would suffer most from this drop in productivity. These countries were already suffering from an ageing of their workforce and high debt burdens. In addition, the article pointed out that promoting innovation by boosting R\&D, expanding access to healthcare, and increasing labour market flexibility could be effective policies to be mitigate the effect of population ageing on aggregate productivity. To conclude, an interesting note from this research was that the authors identified a significant increase in physical capital in line with the increase in the weight of working people between 55 and 64 years of age. Aiyar, Ebeke, and Shao pointed out that this could indicate a specialization of the economies in question in capital-intensive technologies to complement less productive workers-a finding that is in line with what Acemoglu and Restrepo [45] noted shortly thereafter, as discussed below.

Since the two research papers presented are the key reference literature for this research, several ideas should be highlighted. First, Feyrer's [7] article—as well as its extension in Feyrer [9]—is considered to be the seminal article in the research on a possible relationship between labour force ageing and productivity at the aggregate level. In fact, Aiyar et al. [8] cited Feyrer in the scientific literature they took as a reference and the empirical approach they used is the one proposed by this author [8]. In addition, there are a large number of studies that take Feyrer's analyses as the obligatory reference when dealing with the issue $[10,16,21,28,34,46-48]$.

With this in mind, Feyrer [7] seems less categorical in its conclusions than Aiyar et al. [8], since it calls for caution and explicitly states that the evidence its research shows "is not sufficient to establish a causal link between demographic change and productivity growth" [7]. A caution that seems not to be expressly reflected in the work of Aiyar et al.

Another interesting aspect is the use and availability of data. Feyrer [7] demonstrates a concern for complete data series by selecting his sample of countries, and exposes and details how he has constructed his variables and database. This concern is not so present in Aiyar et al. [8]. A final difference is that Feyrer [7] excludes oil-exporting countries from its selection, while Aiyar et al. [8] do consider Norway in their analysis. Finally, despite the similarities and differences between the two researches, it is important to remember that the former is a scientific article published in a reference journal, while the latter is a working paper that will probably evolve with new and interesting findings.

In summary, the possible impact of demographic ageing on aggregate productivity at the country level is an open debate in the literature, and does not yet have extensive research to support it. Although there are several studies and researches on the subject, there is still no general consensus on the variables to be used, their conceptualization or the level of analysis. For this reason, several authors from different backgrounds defend the relevance of carrying out more research along these lines $[7-9,39,45]$.

\section{Empirical Design}

The standard panel data analysis technique will be used using the empirical design outlined in Aiyar et al. [8], which in turn is based on the approach used by Feyrer [7]. It is considered convenient to continue with this design in order to compare the results obtained in this research with the conclusions 
of the work carried out by Aiyar et al. Therefore, the analyzed sample ( 24 countries) is the same as the one studied by these authors (Austria, Belgium, Czech Republic, Denmark, Estonia, Finland, France, Germany, Greece, Hungary, Ireland, Italy, Latvia, Lithuania, Luxembourg, the Netherlands, Norway, Poland, Portugal, Slovak Republic, Slovenia, Spain, Sweden, and the United Kingdom).

The panel data technique gives the possibility of performing a dynamic analysis by incorporating the dimension of time, something that is considered very useful especially in periods of great change [49]. The reference sources for demographic data are OECD and Eurostat, and for productivity data is the Penn World Tables (version 9.0) [50]. The selected time range is from 1983 to 2014, as from 2014, there are no data available to calculate labour productivity in the Penn World Tables (version 9.0). The following section explains in greater depth other motivations for choosing this time range for analysis.

The proposed regression model takes the increase in labour productivity per person employed as an explained or dependent variable $(Y W)$, while the percentage of employed persons between 55 and 64 years of age is included in the model as an explanatory or independent variable (w55_64). Additionally, the youth dependency ratio $(Y O A D R)$, the dependency ratio (OADR), and the fixed effects corresponding to years $(\mu)$ and countries $(\eta)$ are introduced as control variables. $\theta_{1}, \theta_{2}$ and $\theta_{3}$ are the regression coefficients.

The model is set out as follows:

$$
\Delta \log Y W i t=\theta 1 w 55 \_64 i t+\theta 2 Y A D R i t+\theta 3 O A D R+\mu i+\eta t+\varepsilon i t
$$

The variables are as follows:

- $\quad Y W$ : Labour productivity per person employed. It is calculated as the division of real GDP (euros, at constant 2011 prices) between employed persons and is represented as Neperian logarithm and annual increase.

- $\quad w 55 \_64:$ Percentage of people employed between 55 and 64 years of age in relation to the total number of people employed.

- YADR: Young dependency ratio, calculated as the ratio between the number of persons aged 0 to 14 and the number of persons aged 15 to 64 .

- OADR: Dependency ratio, calculated as the number of persons aged 65 or over and the number of persons aged 15 to 64 .

- $\quad \mu$ : Fixed country effect.

- $\eta$ : Year fixed effect.

- $\varepsilon$ : Error term.

- $i$ : Country.

- $t$ : Year.

As specified in Aiyar et al. [8], the coefficient $\theta_{1}$ is expected to be significant and negative, indicating that an increase in the percentage of employed aged between 55 and 64 negatively influences the increase in labour productivity per employed person, even after controlling for the demographic structure represented by the dependency ratio and the youth dependency ratio. This approach assumes that the output (or productivity)-growth ratio is a function of changes in the demographics of the labour force [7], especially the cohort of working people between 55 and 64 years of age. In addition, as specified by Aiyar et al. [8], country-specific fixed effects should absorb the country-specific factors that influence output per working person, while decade-time effects are included to take account of common shocks affecting growth. On the other hand, unlike Feyrer [9] and Aiyar et al. [8], this paper does not address the possible channels through which an ageing labour force affects productivity per person employed, which is one the future lines of research proposed in the Section 6 of this work. In any case, the empirical design proposed is considered sufficient to respond to the objective of this research of contrasting the possible relationship between labour force ageing and labour productivity. 


\subsection{Time Period Analysed: 1983-2014}

It has been decided to focus the research on the 1983-2014 time range because, first, this period has not been contrasted previously in other studies. As explained above, there are few empirical studies analyzing the relationship between ageing and aggregate productivity [21], and the existing examples have checked the relationship for other time periods.

Also, the selected time range covers a sufficient number of years and data, including compelling events that might enrich the analysis. Specifically, during the last period of the 20th century and the beginning of the 21st century, European countries have experienced a pronounced evolution in their rates of population ageing [1]. In addition, a second large wave of productivity growth [23] has been identified in developed economies in the period 1995-2004.

In addition, it is considered that, for the 1983-2014 time range, there are sufficient data for the selected sample of countries, whereas for decades prior to the 1980s, there are no data for a significant number of countries. All these imply not only having a reasonable number of observations in both dimensions of year and country but also favoring a wider variability that can be positive for the empirical contrast, which in turn can help to shed new light on the subject under study.

Finally, it should be noted that the concrete selection of these years seeks to check whether the conclusions of Aiyar et al. [8] are maintained by taking only part of the years analyzed in their research. It should not be forgotten that Acemoglu and Restrepo [45] have found a possible and unexpected positive correlation between population ageing and economic growth, and have proposed the hypothesis that the process of demographic ageing-and the shortage of labour associated with it-could be encouraging firms to substitute labour factor for capital factor through the robotization of their production processes. This idea of Acemoglu and Restrepo is attractive for the present analysis since the possible negative influence of the ageing of the labor force on labor productivity could become diluted if the temporal period 1983-2014 is analyzed, given that the substitution of labor factor by capital factor could lead to an increase in productivity.

\subsection{Data Availability}

An important aspect to consider is the availability of data for the 24 countries selected in the 32-year period analysed. As shown in Table 1, the availability of data for each year in all four relevant variables-labour productivity, percentage of employed persons aged 55 to 64, youth dependency ratio, and dependency ratio-differ across countries. Data are fully available for 13 out of 24 countries, and for all other 11 countries, the number of years for which all four variables are available varies from 15 to 24 years.

Table 1. Number of years in which sample countries submit complete data ${ }^{1}$.

\begin{tabular}{cc}
\hline Country & Years \\
\hline Austria & 21 \\
Belgium & 32 \\
Czech Republic & 22 \\
Denmark & 32 \\
Estonia & 24 \\
Finland & 32 \\
France & 24 \\
Germany & 32 \\
Greece & 32 \\
Hungary & 23 \\
Ireland & 23 \\
Italy & 32 \\
Latvia & 20 \\
Lithuania & 15 \\
Luxembourg & 32 \\
\hline
\end{tabular}


Table 1. Cont.

\begin{tabular}{cc}
\hline Country & Years \\
\hline Netherlands & 32 \\
Norway & 32 \\
Poland & 23 \\
Portugal & 32 \\
Slovak Republic & 21 \\
Slovenia & 15 \\
Spain & 32 \\
Sweden & 32 \\
United Kingdom & 32 \\
\hline${ }^{1}$ Note: The entire period 1983-2014 is made up of 32 years.
\end{tabular}

As can be seen in the table, most of the countries that do not submit data for the whole period belong to Eastern Europe, except in the cases of Ireland, France, and Austria. Data unavailability is concentrated in the 1980s and early 1990s.

\subsection{Evolution and Descriptive Analysis}

Prior to the empirical contrast, a descriptive analysis of the behaviour and evolution of the main variables is carried out. The purpose of this analysis is to better understand their dynamics in the observed time period (1983-2014) and to show their trend throughout it. The evolution of the variables is shown graphically in Figure 1. For the variables dependency ratio, youth dependency ratio and percentage of working people between 55 and 64 years of age, the data are shown until 2017, given that this is the last data available. Meanwhile, the time series for the labour productivity variable runs until 2014 (last year available in Penn World Tables, version 9.0).

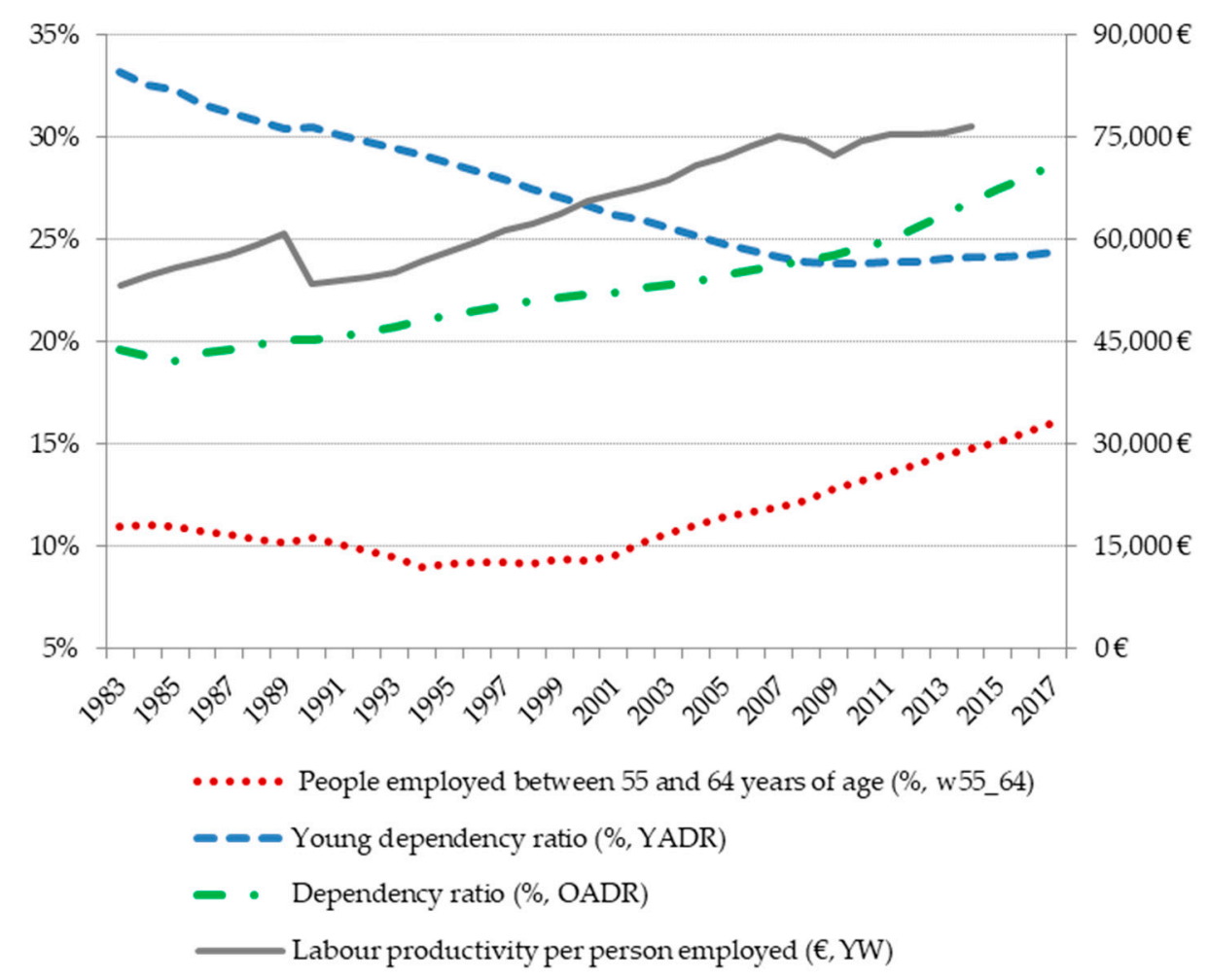

Figure 1. Evolution of variables.

The percentage of people employed between 55 and 64 years old (w55_64) presents a range between $7.3 \%$ and $15.8 \%$, observing a clear increase in the average percentage of employed persons of 
this age cohort from the year 2000. One plausible explanation is that much of the post-Second World War "baby boom" generation has entered this age cohort during this century [1]. Another aspect to highlight is that the weight of this variable depends not only on the number of people between 55 and 64 years of age in a country but also on their level of activity and participation in the labour market.

The dependency ratio $(O A D R)$ is an indicator widely used in demographic studies and, although it has its detractors since it is only fixed at chronological age and not at cognitive or physical age, it is still a widely used measure [51]. As Figure 1 shows, this ratio has progressively increased in recent decades, an aspect that fits with the ageing process that Europe is experiencing [52]. On the contrary, and also in line with the progressive ageing of European countries, the youth dependency ratio (YADR) has followed a downward trend and contracted by 8.8\% between 1983 and 2017 .

Labour productivity shows an upward trend in the period analysed, especially between 1995 and 2004, at which time the literature has identified a wave of productivity growth in the USA and Europe [53]. The graph also shows the negative shocks that the economic crises of 1990 and 2008 had on output per person employed, a result in line with the fact that crises have a negative impact on productivity [23].

\section{Results}

This section presents the results of the empirical contrast and how they respond to the research problem posed, i.e. whether there is a negative relationship between labour force ageing and labour productivity in European countries between 1983 and 2014.

The results in Table 2 show how a 1\% increase in the workforce between the ages of 55 and 64 is significantly related to a $0.106 \%$ decrease in annual growth in labour productivity per person employed. This result is aligned with the effect found by Aiyar et al. [8] for the same sample of countries, as these authors argue that an ageing labour force reduces labour productivity growth. However, Aiyar et al. find a more pronounced negative effect for the period 1950-2014. Specifically, they propose a decrease of $0.165 \%$ of the annual growth of productivity per person employed.

Table 2. Estimation of the effect of labour force ageing on labour productivity.

\begin{tabular}{|c|c|c|c|c|}
\hline Dependent Variables & $\theta$ & Standard Deviation & $t$ & Statistical Significance \\
\hline w55_64 & $-0.1060 *$ & 0.0600 & -1.7610 & 0.0790 \\
\hline YADR & 0.0010 & 0.0410 & 0.0160 & 0.9870 \\
\hline OADR & -0.0460 & 0.0570 & -0.8020 & 0.4230 \\
\hline
\end{tabular}

Another aspect to highlight is that the significance for the result that appears in Table 2 is $7.6 \%$, while those that show the contrasts conducted by Aiyar et al. [8] are less than 5\%. Although this is a relevant issue, such a difference in significance should not invalidate the result and the relevant comparative results [54].

Both Aiyar et al. [8] and Feyrer [7] show in their work their concern about the endogeneity problems that the model may present. In particular, the fact that a positive productivity shock can cause an increase in the participation of people between the ages of 55 and 64 in the labor force. Feyrer [7] discards this possible reverse causality, but Aiyar et al. [8] address it through instrumental variables [55]. This research also carries out this methodology.

First, they instrument the percentage of employed persons between 55 and 64 years of age (w55_64) by the proportion of the population in the 45-54 age group 10 years earlier. Moreover, just in case the effect of the productivity shock on the explanatory variable extends beyond a decade, they also instrument the labour force between 55 and 64 years of age variable and the combined variable of the dependency ratio for the birth rates of 10, 20,30, and 40 years earlier. Aiyar et al. [8] choose to combine the youth dependency ratio $(Y A D R)$ and the dependency ratio $(O A D R)$ into a single ratio $(A D R)$, with 
the aim of reducing the number of variables that need instrumentation, as the number of observations is also reduced. This paper adopts the same approach.

This method makes it possible to obtain unbiased estimates of a possible relationship between the explanatory variable and the explained variable, and specifically seeks to neutralize a possible upward bias in the coefficient $\theta_{1}$. Tables $\mathrm{A} 1$ and $\mathrm{A} 2$ in Appendix A show how the instrumental variables are correlated with the explanatory variables.

As can be seen in Tables 3 and 4, the negative effect of the explanatory variable (w55_64) on the explained variable $(\triangle Y W)$ is greater once the exposed instrumentation is performed. Specifically, for each $1 \%$ increase in the labour force between 55 and 64 years of age, a decrease between $0.191 \%$ (Table 1) and $0.479 \%$ (Table 2) in the annual increase of labour productivity is observed. These results are in line with those obtained by Aiyar et al., which also show an effect in the same direction, although with a greater negative effect given that these authors show a decrease of $0.25 \%$ and $0.7 \%$ in the explained variable performing the same instrumentation.

Another aspect to highlight is that the significance improves using instrumental variables. In Table 2 the significance is $7.6 \%$, while in Tables 3 and 4 it decreases to $1.26 \%$, and to $0.19 \%$, respectively.

Table 3. Estimation of the effect of labour force ageing on labour productivity (external instrument: population aged 45-54 10 years earlier).

\begin{tabular}{|c|c|c|c|c|}
\hline Dependent Variables & $\theta$ & Standard Deviation & $t$ & Statistical Significance \\
\hline w55_64 & $-0.1917 * *$ & 0.0766 & -2.5 & 0.0126 \\
\hline YADR & 0.0149 & 0.0415 & 0.36 & 0.7194 \\
\hline OADR & -0.0574 & 0.0579 & -0.99 & 0.3215 \\
\hline
\end{tabular}

Table 4. Estimation of the effect of the labour force ageing on labour productivity (external instrument: birth rates 10, 20,30, and 40 years earlier).

\begin{tabular}{|c|c|c|c|c|}
\hline Dependent Variables & $\theta$ & Standard Deviation & $t$ & Statistical Significance \\
\hline w55_64 & $-0.4793^{* * *}$ & 0.1531 & -3.13 & 0.0019 \\
\hline $\begin{array}{l}\text { ADR (Combined } \\
\text { Dependency ratio) }\end{array}$ & 0.1234 & 0.0876 & 1.41 & 0.1602 \\
\hline
\end{tabular}

Finally, in order to check the robustness of the model, the contrast shown in Tables 3 and 4 (with instrumental variables) has been conducted by calculating the labour productivity variable per hour worked, and not per employed person. This modification of the explained variable seeks to contrast if the exposed results are robust [8], especially considering that the labor productivity variable has been constructed without taking into account the differences in hours worked between countries [7].

Tables 5 and 6 show how the negative and significant relationship between the variables analysed is maintained in the two instrumentations carried out, even measuring labour productivity per hour worked, which indicates the robustness of the model and the effects previously exposed.

Table 5. Effect of ageing on labour productivity per hour worked (external instrument: population aged 45-54 10 years earlier).

\begin{tabular}{|c|c|c|c|c|}
\hline Dependent Variables & $\theta$ & Standard Deviation & $t$ & Statistical Significance \\
\hline w55_64 & $-0.2252^{* *}$ & 0.0921 & -2.44 & 0.0148 \\
\hline YADR & 0.0797 & 0.0663 & 1.2 & 0.2299 \\
\hline OADR & $-0.1949 * *$ & 0.0825 & -2.36 & 0.0186 \\
\hline
\end{tabular}


Table 6. Effect of ageing on labour productivity per hour worked (External instrument: birth rates 10, 20,30 , and 40 years earlier).

\begin{tabular}{|c|c|c|c|c|}
\hline Dependent Variables & $\theta$ & Standard Deviation & $t$ & Statistical Significance \\
\hline w55_64 & $-0.7222 * * *$ & 0.206556 & -3.5 & 0.0005 \\
\hline $\begin{array}{l}\text { ADR (Combined } \\
\text { Dependency ratio) }\end{array}$ & -0.0746 & 0.118832 & -0.63 & 0.5304 \\
\hline
\end{tabular}

\section{Discussion}

In the light of these results, the hypothesis that the increase in the labour force between 55 and 64 years of age is negatively related to labour productivity can be confirmed, so that the present research advances on the path opened by Feyrer [7,9] and, specifically, reinforces the conclusions of Aiyar et al. [8] regarding the impact of ageing on labour productivity in Europe.

In any case, it is interesting to note that the negative relationship between labour force ageing and productivity appears to be tempered if a more recent period (1983-2014) is analysed as opposed to a longer period of time (1950-2014). This lesser influence may be given by the specialization in capital-intensive technologies that Aiyar et al. [8] seem to identify in the European countries analyzed. The purpose of this specialization would be to counteract the ageing and loss of productivity of their respective labour forces. This idea can be combined with the one put forward by Acemoglu and Restrepo [45], who argue that they have found a possible positive effect of population ageing on economic activity. This effect would consist in the fact that the ageing phenomenon would be driving in recent decades the robotization and automation of production processes in certain countries, which in turn would have a positive influence on the productivity of their economies.

If this reflection is framed in the period of time analyzed in the present article, it is relevant to point out that there is a decade (1995-2004) in which there is a strong productivity growth. The scientific consensus is that productivity growth has historically occurred through large waves or moments of acceleration after years of sluggishness or moderate growth. The first great wave experienced by the USA after the First World War-and by Japan and certain European countries after the Second World War-is widely analyzed and accepted in literature [56-58]. A second large wave of productivity growth that appeared in the USA and European countries between 1995 and 2004 has also been identified [19,59]. Oliner and Sichel [60] show that information technologies are responsible for the increase in labour productivity in this second big wave that began at the end of the 20th century, and the development of these technologies led to an investment effort in capital and knowledge-intensive sectors.

Bearing this in mind, the lower negative ratio of workforce ageing to labour productivity observed by this research between 1983-2014 (between $-0.106 \%$ and $-0.479 \%$ ) in relation to the $1950-2014$ period analysed by Aiyar et al. (between $-0.165 \%$ and $-0.7 \%$ ) may be due to the progressive specialisation of the European countries in technologically advanced economic sectors and with a greater relative weight of the capital factor over the labour factor. This, in turn, is in line with the proposal that the impact of ageing on productivity may be sensitive to the structure of the economy [8].

This idea is also consistent with Skirbekk's [16] reflections that the competences and skills of the working person can evolve both positively and negatively with age. In this sense, it seems logical to assume that an economic activity with a greater weight of technology and/or knowledge-intensive sectors may be less exposed to a possible negative effect of workforce ageing given that, for example, communication skills and experience-important in a knowledge-intensive economy-can increase and improve over the years. While other skills such as physical strength, more relevant in less advanced economies focused on labour-intensive sectors, tend to deteriorate as the age of the working person increases.

The results shown by the quantitative check carried out advance in the deepening and greater understanding of the phenomenon of population ageing. This is an important research task given that there are certain preconceived ideas and false beliefs about it. In this sense Rowe [61] exposes 
that certain false beliefs exist in relation to demographic ageing, and defends that these should be analyzed and refuted empirically. Börsch-Supan [14] also points out that knowledge about ageing falls into certain beliefs that must be analysed scientifically in order to identify the true socio-economic challenges it poses.

Along these lines, there are authors who defend a non-alarmist view of demographic analysis, as well as an understanding of the ageing phenomenon from a revised and systemic point of view. These include Cutler, Poterba, Sheiner, and Summers' early analysis of ageing and macroeconomic change [62]; Vincent's critical examination of demographic scaremongering [63]; the development of the concept of the "longevity dividend" [64,65]; the interesting report by the Joint Academy Initiative on Aging [12], Börsch-Supan's own ideas [3] on ageing, the labour market, and well-being; the study of the ageing phenomenon without falling into an apocalyptic vision by Waldbrook, Rosenberg, and Brual [66]; and, finally, the analyses carried out on the relativity of chronological time and images of ageing [67].

In the light of the results of the empirical contrast presented, the negative impact of population ageing on labour productivity constitutes a real socio-economic challenge for European countries, rather than a false demographic belief. The results exposed reinforce the idea of Aiyar et al. [8] that the progressive increase in the workforce age in European societies can damage their labour productivity and consequently have a significant impact on their productivity and public services, since population ageing not only adds pressure on public accounts through greater spending on, for example, health care or pensions $[3,6,25,68,69]$, but also on their production model by causing lower productivity growth.

However, it should not be ruled out the possibility that the progressive evolution of an economy towards capital and/or knowledge-intensive sectors may dilute-and even neutralize-the negative impact of the workforce ageing on labour productivity. In this sense, the lesser influence found by this research in the period 1983-2014 with respect to that found by Aiyar et al. in the years 1950-2014 may reflect an evolution of the European economy toward this typology of sectors. If this point is proven, Skirbeek's idea [40] that the European labour market and economy are not flexible enough to accommodate the effects of the progressive ageing of its labour force would be put into perspective. Obviously, contrasting this hypothesis is not the objective of this article, so it needs additional research.

\section{Conclusions, Limitations and Future Lines of Research}

The objective of this research is to check the impact of workforce ageing on labour productivity in a sample of 24 European countries between 1983 and 2014. A significant and negative relationship between the studied variables has been identified through the panel data technique. Specifically, it has been found that each 1\% increase in the employed population between the ages of 55 and 64 is related to a decrease of the annual increase in productivity between $-0.106 \%$ and $-0.479 \%$. This effect is in line with the results of the analysis carried out by Aiyar et al. [8] for the same sample of countries between 1950 and 2014, although the effect is less than that found by these authors.

The major contribution of this research is to continue developing the path opened by Feyrer [7,9] and later taken up by Aiyar et al. [8] on the influence of population ageing on aggregate labour productivity, a research area that presents surprisingly little literature [21]. Especially considering that demographic ageing will be one of the main global trends during this century, and the relevance of its influence on the economy, employment and the social and care systems sustainability. In addition, the check of the possible influence of population ageing on labour productivity had not been carried out for the period 1983-2014, an interesting time span given that it contains the years in which the USA and European countries experienced a wave of productivity growth, while Europe also presents an acceleration of the increase of its ageing process.

The limitations of this research are based on the fact that several countries in the sample do not have complete data series for the period analysed, especially those belonging to Eastern Europe. In addition, a purely economic conceptualization and measurement of the productivity variable has been chosen, without taking into account the voices that claim that in the working environment 
the working person is also intellectually, emotionally and/or motivationally productive [70]. Finally, this analysis takes chronological age as the basis for demographic variables, rather than cognitive or physical age, which could be a more accurate way to measure the age of the working population. In any case, it is considered that the contrast carried out presents sufficient data series to present solid empirical results, that the metric used for the productivity variable is widely accepted in the literature, and that the chronological age is also valid and widely used.

The future lines of research that can be derived from this work are to delve deeper into the causal mechanisms that provoke a negative relationship between the variables under study, to continue advancing in the understanding of the hypothesis put forward by Acemoglu and Restrepo in order to better understand the possible substitution of labour factor for capital factor that is being carried out by ageing countries, the inclusion of more control variables to further contrast the relationship between ageing and productivity, the specific analysis of the age cohort of workers over 65 years old, the interaction between the progressive workforce ageing and the expansion of new technologies, and, finally, to advance in overcoming the aforementioned "level myopia" when analysing the impact of ageing at different levels of productivity.

Population ageing is a demographic success story, since it is associated with great social and economic advances $[1,71]$. This process will continue and accelerate across almost all countries around the globe. Therefore, a greater and better understanding of the phenomenon is in the interests of a wide range of fields of knowledge. The effect of workforce ageing on labour productivity stands out as one of them, due to the importance of productivity in the future of the economy, the welfare system's sustainability, and the well-being of the population.

Author Contributions: Conceptualization, I.C.-S. and R.A.; Methodology, I.C.-S. and J.P.L.; Software, J.P.L.; Validation, I.C.-S., J.P.L. and R.A.; Formal analysis, I.C.-S. and J.P.L.; Investigation, I.C.-S. and J.P.L; Resources, I.C.-S., J.P.L. and R.A.; Data curation, I.C.-S. and J.P.L.; Writing—original draft preparation, I.C.-S.; Writing-review and editing, I.C.-S., R.A., and J.P.L.; Visualization, I.C.-S.; Supervision, R.A.; Project administration, I.C.-S., J.P.L., and R.A.; Funding acquisition, I.C.-S. and R.A.

Funding: This paper has been financially supported by the Fundación Jesús de Gangoiti Barrera, the Fundación Luis Bernaola and Deiker of the University of Deusto.

Acknowledgments: We thank the Robert N. Butler Columbia Aging Center team at Columbia University and its former director, Ursula M. Staudinger, and Shekhar Aiyar, Christian Ebeke and Xiaobo Shao of the European Department of the International Monetary Fund who provided insight for the research, although they may not agree with all of conclusions of the paper. We also appreciate feedback from the anonymous reviewers on early drafts of this paper. The authors thank Fundación Jesús de Gangoiti Barrera, Fundación Luis Bernaola and Deiker for the financial support.

Conflicts of Interest: The authors declare no conflict of interest.

\section{Appendix A}

Instrumental equations:

Table A1. Instrumental equations using lagged population share 45-54.

\begin{tabular}{cc}
\hline & w55_64 \\
\hline Population share $45-54 \mathrm{t}-10$ & $1.3466^{* * *}$ \\
& $(31.35)$ \\
\hline Observations & 633 \\
No of countries & 24 \\
F at first stage & 222.7 \\
\hline${ }^{* * *}, \mathrm{p}<0.01 ;{ }^{* *}, \mathrm{p}<0.05 ;{ }^{*}, \mathrm{p}<0.1$.
\end{tabular}


Table A2. Instrumental equations using lagged birth rates.

\begin{tabular}{cc}
\hline & w55_64 \\
\hline Birth rate $\mathrm{t}-40$ & $-0.00218^{* * *}$ \\
& $(5.07)$ \\
\hline Birth rate $\mathrm{t}-30$ & $-0.00211^{* * *}$ \\
& $(4.36)$ \\
\hline Birth rate $\mathrm{t}-20$ & $-0.00418^{* * *}$ \\
& $(9.51)$ \\
\hline Birth rate $\mathrm{t}-10$ & $-0.00608^{* * *}$ \\
& $(8.46)$ \\
\hline Observations & 359 \\
No of countries & 24 \\
F at first stage & 110.06 \\
\hline$* * *, \mathrm{p}<0.01 ;{ }^{* *}, \mathrm{p}<0.05 ;{ }^{*}, \mathrm{p}<0.1$.
\end{tabular}

\section{References}

1. United Nations. World Population Ageing 2017; United Nations: New York, NY, USA, 2017.

2. Reynaud, C.; Miccoli, S. Depopulation and the Aging Population: The Relationship in Italian Municipalities. Sustainability 2018, 10, 1004. [CrossRef]

3. Börsch-Supan, A. Ageing, labour markets and well-being. Empirica 2013, 40, 397-407. [CrossRef]

4. Popescu, M.E.; Militaru, E.; Cristescu, A.; Vasilescu, M.D.; Matei, M.M.M. Investigating health systems in the European Union: Outcomes and fiscal sustainability. Sustainability 2018, 10, 3186. [CrossRef]

5. Dumas, A.; Turner, B.S. Aging in post-industrial societies: Intergenerational conflict and solidarity. In The Welfare State in Post-Industrial Society: A Global Perspective; Powell, J., Hendricks, J., Eds.; Springer Publishing Company: New York, NY, USA, 2009; pp. 41-56.

6. European Commission. The 2018 Ageing Report: Underlying Assumptions \& Projection; European Commission: Luxembourg, 2017.

7. Feyrer, J. Demographics and Productivity. Rev. Econ. Stat. 2007, 89, 100-109. [CrossRef]

8. Aiyar, S.; Ebeke, C.; Shao, X. The Impact of Workforce Aging on European Productivity; IMF Working Paper WP/16/238; International Monetary Fund: Washington, DC, USA, 2016.

9. Feyrer, J. Aggregate Evidence on the Link between Age Structure and Productivity. Popul. Dev. Rev. 2008, 34, 78-99.

10. Maestas, N.; Mullen, K.J.; Powell, D. The Effect of Population Aging on Economic Growth, the Labor Force and Productivity; RAND Working Paper WR-1063-1; RAND Corporation: Santa Monica, CA, USA, 2016.

11. Göbel, C.; Zwick, T. Age and productivity: Sector differences. De Economist 2012, 160, 35-57. [CrossRef]

12. Joint Academy Initiative on Aging. More Years, More Life. Recommendations of the Joint Academy Initiative on Aging (Translation of 'Gewonnene Jahre'-Altern in Deutschland Band 9, Nova Acta Leopoldina Band 107, Nummer 371); Präsidium der Deutschen Akademie der Naturforscher Leopoldina-Nationale Akademie der Wissenschaften: Halle, Germany, 2010.

13. Grund, C.; Westergaard-Nielsen, N. Age structure of the workforce and firm performance. Int. J. Manpow 2008, 29, 410-422. [CrossRef]

14. Börsch-Supan, A. Myths, scientific evidence and economic policy in an aging world. J. Econ. Ageing 2013, 2, 3-15. [CrossRef]

15. De Sivatte, I.; Olmos, R.; Simón, C.; Martel, M. El efecto de la edad, la experiencia y la formación en la productividad laboral. Cuadernos de Información Económica 2018, 263, 13-24.

16. Skirbekk, V. Age and productivity capacity: Descriptions, causes and policy options. Ageing Horiz. 2008, 8, 4-12.

17. Skirbekk, V. Age and Individual Productivity: A Literature Survey. Vienna Yearb. Popul. Res. 2004, 2, $133-153$. [CrossRef]

18. Veen, S. Demographischer Wandel, Alternde Belegschaften und Betriebsproduktivität; Rainer Hampp Verlag: Munich, Germany, 2008. 
19. Fernald, J.; Thipphavong, D.; Trehan, B. Will Fast Productivity Growth Persist? FRBSF Econ. Lett. 2007, 2, $1-4$.

20. Lindh, T. Productivity Is a System Property and Need Not Decrease with the Age of the Workforce. Vienna Yearb. Popul. Res. 2005, 3, 7-9. [CrossRef]

21. Liu, Y.; Westelius, N. The Impact of Demographics on Productivity and Inflation in Japan. J. Int. Commer. Econ. Policy 2016, 8, 1-16. [CrossRef]

22. United Nations. World Population Prospects 2017; United Nations-Department of Economic and Social Affairs PD: New York, NY, USA, 2017; Available online: https://esa.un.org/unpd/wpp/publications/Files/ WPP2017_KeyFindings.pdf (accessed on 15 January 2018).

23. Bergeaud, A.; Cette, G.; Lecat, R. Productivity Trends in Advanced Countries between 1890 and 2012. Rev. Income Wealth 2016, 62, 420-444. [CrossRef]

24. Chand, M.; Tung, R.L. The aging of the world's population and its effects on global business. Acad. Manag. Perspect. 2014, 28, 409-429. [CrossRef]

25. Harper, S. Economic and social implications of aging societies. Science 2014, 346, 587-591. [CrossRef]

26. Zhao, S.; He, J.; Yang, H. Population ageing, financial deepening and economic growth: Evidence from China. Sustainability 2018, 10, 4627. [CrossRef]

27. Bloom, D.E.; Canning, D.; Fink, G. Implications of population ageing for economic growth. Oxford Rev. Econ. Policy 2010, 26, 583-612. [CrossRef]

28. Poot, J. Demographic Change and Regional Competitiveness: The Effects of Immigration and Ageing; Population Studies Centre (PSC) Discussion Papers 64; University of Waikato: Hamilton, New Zealand, 2008.

29. Aranguren, M.J.; Kamp, B. Competitividad Territorial. Boletín Estud. Económicos 2014, LXIX, 517-532.

30. Bourdelais, P. Demographic aging: A notion to revisit. Hist. Fam. 1999, 4, 31-50. [CrossRef]

31. Kirk, D. Demographic transition theory. Popul. Stud. 1996, 50, 361-387. [CrossRef] [PubMed]

32. Reher, D.S. Economic and social implications of the demographic transition. Popul. Dev. Rev. 2011, 37, 11-33. [CrossRef]

33. Marešová, P.; Mohelská, H.; Kuča, K. Economics Aspects of Ageing Population. Procedia Econ. Financ. 2015, 23, 534-538. [CrossRef]

34. Oliver, M. Population ageing and economic growth in Japan. Int. J. Sociol. Soc. Policy 2015, 35, 841-863. [CrossRef]

35. Luo, B. China will get rich before it grows old: Beijing's demographic problems are overrated. Foreign Aff. 2015, 94, 19-24.

36. Bloom, D.E.; Sousa-Poza, A. Ageing and Productivity; FZID Discussion Paper 63-2012; Universität Hohenheim: Stuttgart, Germany, 2013.

37. Börsch-Supan, A.; Weiss, M. Productivity and age: Evidence from work teams at the assembly line. J. Econ. Ageing 2016, 7, 30-42. [CrossRef]

38. Hagestad, G.O.; Dannefer, D. Concepts and Theories of Aging. In Handbook of Aging and the Social Sciences, 5th ed.; Binstock, R.H., George, L.K., Eds.; Academic Press Inc.: Burlington, VT, USA, 2001; pp. 3-21.

39. Prskawetz, A. Will Population Ageing Decrease Productivity? Summary of the Debate. Vienna Yearb. Popul. Res. 2005, 3, 1-3. [CrossRef]

40. Skirbekk, V. Population Ageing Negatively Affects Productivity. Vienna Yearb. Popul. Res. 2005, 1, 5-6. [CrossRef]

41. Prskawetz, A. Background and Summary of the Symposium on 'Population Ageing and Economic Productivity'. Vienna Yearb. Popul. Res. 2005, 3, 11-15.

42. Gans, D.; Putney, N.M.; Bengston, V.L.; Silverstein, M. The Future of Theories of Aging. In Handbook of Theories of Aging, 2nd ed.; Silverstein, M., Bengtson, V.L., Putnam, M., Putney, N.M., Gans, D., Eds.; Springer Publishing Company: New York, NY, USA, 2009; pp. 721-737.

43. Gschwend, T.; Schimmelfennig, F. Introduction: Designing Research in Political Science-A Dialogue between Theory and Data. In Research Design in Political Science: How to Practice What They Preach; Gschwend, T., Schimmelfennig, F., Eds.; Palgrave Macmillan UK: London, OH, USA, 2007; pp. 1-20.

44. Babbie, E. The Basics of Social Research, 5th ed; Wadsworth: Belmont, MA, USA, 2013.

45. Acemoglu, D.; Restrepo, P. Secular stagnation. In The Effect of Aging on Economic Growth in the Age of Automation; NBER Working Paper Series 23077; National Bureau of Economic Research: Cambridge, MA, USA, 2017. 
46. Bussolo, M.; Koettl, J.; Sinnott, E. Golden Aging: Prospects for Healthy, Active, and Prosperous Aging in Europe and Central Asia; World Bank: Washington, DC, USA, 2016.

47. Malmberg, B.; Lindh, T.; Halvarsson, M. Productivity consequences of workforce aging: Stagnation or Horndal effect? Popul. Dev. Rev. 2008, 34, 238-256.

48. Kögel, T. Youth dependency and total factor productivity. J. Dev. Econ. 2005, 76, 147-173. [CrossRef]

49. Mayorga, M.; Muñoz, E. La Técnica de Datos de Panel Una Guía Para su Uso e Interpretación; Banco Central de Costa Rica-División Económica: San José, Costa Rica, 2000.

50. Feenstra, R.C.; Inklaar, R.; Timmer, M.P. The Next Generation of the Penn World Table. Am. Econ. Rev. 2015, 105, 3150-3182. [CrossRef]

51. Muszyńska, M.M.; Rau, R. The Old-Age Healthy Dependency Ratio in Europe. J. Popul. Ageing 2012, 5, 151-162. [CrossRef] [PubMed]

52. European Commission. The 2015 Ageing Report: Economic and budgetary projections for the EU-27 Member States (2013-2060); European Commission: Luxembourg, 2015.

53. Cette, G.; Fernald, J.; Mojon, B. The pre-Great Recession slowdown in productivity. Eur. Econ. Rev. 2016, 88, 3-20. [CrossRef]

54. Amrhein, V.; Greenland, S.; Mcshane, B. Retire statistical significance. Nature 2019, 567, 305-307. [CrossRef]

55. Staiger, D.; Stock, J.H. Instrumental Variables Regression with Weak Instruments. Econometrica 1997, 65, 557-586. [CrossRef]

56. Gordon, R.J. Two Centuries of Economic Growth: Europe Chasing the American Frontier; NBER Working Paper Series 10662; National Bureau of Economic Research: Cambridge, MA, USA, 2004.

57. Gordon, R.J. U.S. economic growth since 1870: One big wave? Am. Econ. Rev. 1999, 89, 123-128. [CrossRef]

58. Fernald, J. Productivity and Potential Output before, during, and after the Great Recession. NBER Macroecon. Аnпu. 2015, 29, 1-51. [CrossRef]

59. Jorgenson, D.W. Information Technology and the US Economy. Am. Econ. Rev. 2001, 91, 1-32. [CrossRef]

60. Oliner, S.D.; Sichel, D.E. The Resurgence of Growth in the Late 1990s: Is Information Technology the Story? J. Econ. Perspect. 2000, 14, 3-22. [CrossRef]

61. Rowe, J.W. Facts and Fictions About an Aging America. Contexts 2009, 8, 16-21.

62. Cutler, D.M.; Poterba, J.M.; Sheiner, L.M.; Summers, L.H. An Aging Society: Opportunity or Challenge? Brookings Pap. Econ. Act. 1990, 1, 1-56. [CrossRef]

63. Vincent, J. Who's afraid of an ageing population? Nationalism, the free market, and the construction of old age as an issue. Crit. Soc. Policy 1996, 16, 3-26. [CrossRef]

64. Olshansky, S.J.; Perry, D.; Miller, R.A.; Butler, R.N. Pursuing the Longevity Dividend: Scientific Goals for an Aging World. Ann. N. Y. Acad. Sci. 2007, 1114, 11-13. [CrossRef] [PubMed]

65. Olshansky, S.J.; Perry, D.; Miller, R.A.; Butler, R.N. In pursuit of the longevity dividend. Science 2006, 20, 28-36.

66. Waldbrook, N.; Rosenberg, M.W.; Brual, J. Challenging the myth of apocalyptic aging at the local level of governance in Ontario. Can. Geogr. 2013, 57, 413-430. [CrossRef]

67. Staudinger, U.M. Images of Aging: Outside and Inside Perspectives. Annu. Rev. Gerontol. Geriatr. 2015, 35, 187-209. [CrossRef]

68. Beard, J.R.; Bloom, D.E. Towards a comprehensive public health response to population ageing. Lancet 2015, 385, 658-661. [CrossRef]

69. Rosenberg, M.W.; Moore, E.G. The health of Canada's elderly population: Current status and future implications. Can. Med. Assoc. J. 1997, 157, 1025-1032.

70. Staudinger, U.M.; Bowen, C.E. A systemic approach to aging in the work context. J. Labour Mark. Res. 2011, 44, 295-306. [CrossRef]

71. Achenbaum, W.A. Past as Prologue: Toward a Global History of Ageing. In The SAGE Handbook of Social Gerontology; Dannefer, D., Phillipson, C., Eds.; Sage: London, UK, 2010; pp. 20-32.

(C) 2019 by the authors. Licensee MDPI, Basel, Switzerland. This article is an open access article distributed under the terms and conditions of the Creative Commons Attribution (CC BY) license (http://creativecommons.org/licenses/by/4.0/). 